\title{
Extended Informatics Paradigm in Biological and Psychological Education
}

\author{
Dobilas KIRVELIS, Kastytis BEITAS \\ Vilnius University, Department of Biochemistry and Biophysics \\ M.K.Čiurlionio 21/27, 2009 Vilnius, Lithuania \\ e-mail:dobilas.kirvelis@gf.vu.lt, kastytis.beitas@gf.vu.lt
}

Received: April 2003

\begin{abstract}
The aim of this work is to present extended informatics paradigm (EIP). This paradigm expands concept of informatics from traditional information and communication technologies (ICT) to a wide use of informational thinking, databases and related technologies in biology and psychology. The essential difference of EIP is an especial attention to nature and purpose of information in organized biological and/or psychological systems. Information as a phenomenon appeared on the Earth 3-4 billion years ago, when the life originated. Informatics paradigm considers the physical and chemical transformations of energy and matter as flows that are controlled, or as the signals for purposive informational control programs. Brain as product of biological evolution accomplishes a quick information processing, thinking and psychical activity. The information is born in control systems of organized systems. The organized systems are represented as informational closed-loop coding-decoding structures. Therefore, the scope of bioinformatics which is generally taught as a skill to deal with biological data bases should be extended, as well as the subject of informational psychology.
\end{abstract}

Key words: information, control, organised system, coding-decoding, bioinformatics.

\section{Introduction}

A new approach emerged in sciences fifty years ago, when cybernetics, information and automatic regulation theories appeared, and computers were invented. It was beginning of information paradigm that had become basis for new comprehension of living nature, humanitarian and social phenomena in terms of information and control systems.

Physical and chemical thinking that is oriented to energy and matter transformations predominated in sciences till this moment. And they are heading the list of scientific paradigms today. Paradigms of natural selection and functional approach dominated earlier and they dominate now in biology. But these materialistic paradigms are insufficient for a full kenning of biological and psychological phenomena. Many thinkers who have investigated the essence of life as biological phenomenon since times of Plato and Aristotle felt the necessity for mystic-like forces as psyche, entelechy, soul, archeus, vis Vitalis. All these hypothetical forces were understood as special forces that are immeasurable but act as organizing, purposeful, controlling factors that are characteristic for organic 
(living) things. At time of prevailing of physical and chemical thinking in sciences practically all materialistic thinkers and scientists perceived them as mystic forces, so use of them in materialistic science was reprehensible and rejected as unscientific.

Religious and philosophical concepts of soul and consciousness are important in humanitarian cognition. Soul is often perceived as mentality or psychics in psychology and philosophy. But these concepts can be reconstructed from the new informational point of view. Informatics paradigm gives a possibility to reintroduce soul and consciousness concepts to scientific view of world and vindicates them from purely mystic perceiving.

The brisk development of information and communication technologies has had great influence upon information paradigm. On the basis of information paradigm the informatics paradigm has developed. The domination of information technologies had evoked up the opinion that industrial society is changing to knowledge society. This conversion may be more important for the scientific worldview than emerging of industrial society from agrarian society after appearance of steam-engines and machine-tools two centuries ago. The upgrade of thinking to quantitative level and mathematization of physics and chemistry was a basis for prosperity of industrial society. Now the need to reintegrate information paradigm and informatics paradigm arises. The extended informatics paradigm (EIP) that is presented here is a product of this integration. EIP drastically changes understanding of living world and especially of world of psychic phenomena. It gives a hope to base the humanities and culture sciences on quantitative estimations and mathematical models.

It is necessary to discuss use of adjectives information and informational. Usual meanings of adjective information are 'relating to information' or 'giving information, informing' (Merriam-Webster Unabridged, 2002). But here is a new tradition to use informational with meaning 'related to economics/society/culture that is restructured by wide use of modern ICT' (it is based mainly on Castells works (Castells, 1989; Castells, 1998)) or 'related to extended use of modern ICT'. The term information paradigm nominates the more classical information paradigm on nature of information and control in all domains of world and their interrelations (it is presented in Section 3 in this paper). Informational paradigm sometimes means the same as information paradigm. But often the term informational paradigm competes with term informatics paradigm in meaning that is related to a wide use of modern ICT in economics, education, research etc. This article is aimed to extended informatics paradigm that is an alloy of information paradigm and informatics paradigm with a stress to information and control nature in "natural biological and psychological information technologies" as they exist in living nature, in human mind and in human society.

Informational thinking in a new knowledge society cannot be limited to "know-how" of informatics technologies. More deep changes of society can be conjured up by more full understanding of live nature (biosphere) and human mind (noosphere) that will emerge from wide use of EIP in biology and biotechnologies, in psychology, anthropology and social sciences. That is possible, if this new knowledge will be disseminated in society, of course. The heralds of extended informatics paradigm in sciences are bioinformatics (in a wide interpretation) and informational psychology. The last is a potential 
branch of psychology that studies psychological influence of wide ICT use and psychological problems of person in knowledge society.

The concepts of signal, information, memory, encoding and decoding, regulation and control and their place in functional structure of organized systems must be clarified before discussion of educological programs of bioinformatics and psychoinformatics.

In Section 2 the nature of information and control, some characteristics of organized systems, and the interpretation of control as coding/decoding are discussed. In Section 3 the informational interpretation of biosystems is presented. The necessary components of bioinformaticist's education are discussed in Section 4 and of psychologists education in Section 5. The new field that studies evolving and interacting information units (and includes memetics) is presented in Section 6.

\section{Information and Control in the Organized Systems}

Information on the Earth has appeared 3-4 billion years ago together with the life, when the dynamical systems of enzyme reactions (dynamic states) were reflected on the stable states of nucleic acids. It was a time when symbiosis of enzymes and nucleic acids has emerged.

The closed-loop system of coding-decoding was a basis for formation of the organized systems, where information processes determined the transformations of matter and energy, i.e., selective actions of the systems (Kirvelis, 1998; 1999; 2000a).

The simplest understanding of information may be represented as relations of two subsystems, controlling and controlled (Fig. 1 (Kirvelis, 1997a; 2000a)). This is the essence of cybernetic or relative information. It means that the state of controlling subsystem governs the state of controlled subsystem, and that information of controlling subsystem

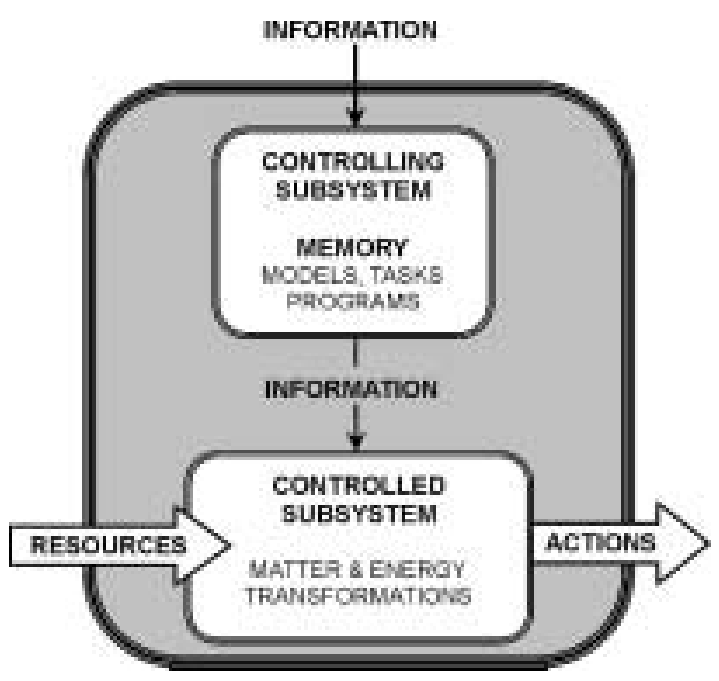

Fig. 1. The simplest organized (control) system and representation of informational control. 
purposefully directs matter, energy or information flows. This is a decoding procedure, too. The subject of an information, control and decoding is the same. The complex system that consists of functionally cooperating information and matter/energy subsystems represents cybernetic or organized system.

Wiener was the first who turned one's attention to the key importance of informational control processes for life. Fifty years ago he wrote that cybernetics is the science of control and control systems, i.e., of information processes in living organisms, some machines and society. H. von Förster (1948) and later M. Conrad (1972) were pioneers in investigations of biological information processing. We know the Wiener's information conception: "Information is Information, neither matter nor energy" and Wiener/Shannon's formula of information quantity. C.E. Shannon's information is structural information. It is removed uncertainty and corresponds to information in memory structures. Memory structures are related with the coding-decoding procedures. The code is a structural agreement between the sender and the receiver of information. Rosen (1985) describes complex relations of systems as unspecified sort of coding problems. Hubwieser (2001) and Breier (2002) represent the coding-decoding procedure similarly. Only they entitle the coding-decoding as representation-interpretation accordingly.

The classic Shannon system - channel of memory or information transfer by communication line - implements an open coding-decoding. Therefore Shannon's theory ignores the sense of the transferred information and discards semantics. Biological, psychological, and social systems are more complex systems with closed-loop coding-decoding.

Life as phenomenon is a functioning of self-reproducable hierarchically developing system that relies on closed-looped bioinformation coding-decoding procedures. This process is dominated by informational control that is object of cybernetics.

In development of the concept of life as an organized system, it was noticed that abstract terms information and control induce some misunderstanding when applied to the functional organization of life. The terms of information and control are more correctly comprehended when they are explained through the closed-looped codingdecoding procedures and information processing mechanisms (Kirvelis, 2001a; 2002a). Encoded/decoded symbols of message get their functional sense when informational channel is closed through the controlled object. This is achieved by coupling of encoders and decoders to particular controlled object through the corresponding receptors and effectors (Fig. 2). External receptors and (coders) take the information about environment for the creation of models of external world. And internal information that is got through internal receptors and coders is used for internal subsystem model. Informational external and internal models are necessary to implement control by decoding through effectors. Decoding in purposeful system becomes the control by information, and all this system can develop to an anticipatory system.

The concept of an organized coding-decoding system explains the biological phenomena from a point of view of functional organization, cybernetics, control and information theory. Physical and chemical transformations of energy and matter in the controlling aspect are considered as means (signal) for implementation of some programs of goaloriented control (Kirvelis, 2000c; 2002b), or as processes that must be controlled. 


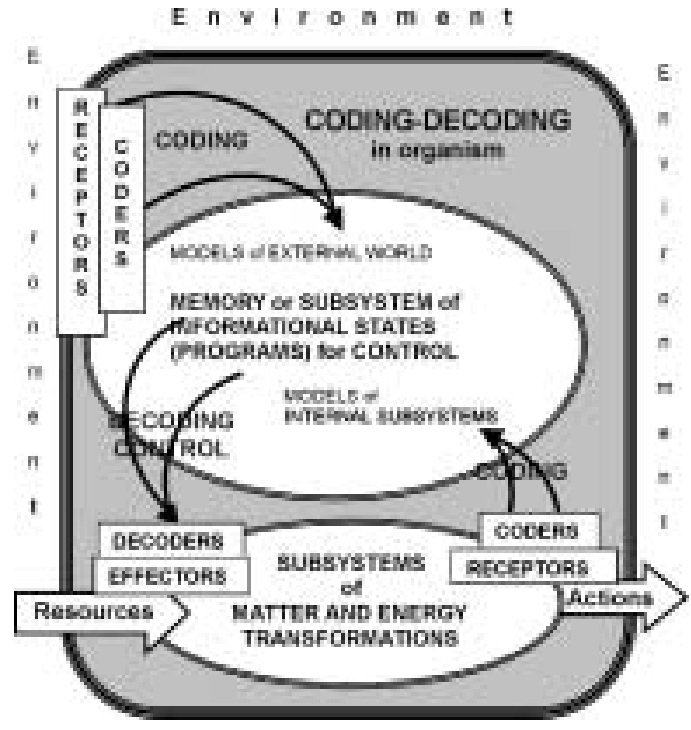

Fig. 2. Closed-Loop Coding-Decoding or the organized (cybernetics) combined control by information system.

Control systems of three types are known: feedforward systems, feedback systems and systems with combined feedforward-feedback information flow. A complete organized system in general is a combined system (Fig. 2). The important difference among these types of systems is a type of information processing used in regulation. In addition, there are few types of qualitatively different adaptive mechanisms, depending upon whether the adaptive loop is feedback or feedforward, and whether the adaptive loop possesses memory or not.

A more general point of view to biological, psychological, social, robotic systems from closed-loop coding-decoding positions induce new informatics paradigm (Kirvelis, 2002a).

\section{Natural Information Technologies in Biosystems}

The quintessence of the information paradigm is represented in Fig. 3. Every organised system (biological, psychological, social, robotic) has dualistic nature - it consists of real matter/energy sphere and virtual information sphere. According Rosen (1985) and Casti (1989) the natural system $\mathbf{N}$ of real world sphere may be represented by encoding (coding) procedure on the formal (abstract, mathematical, virtual, computer) world sphere $\mathbf{F}$ as model of $\mathbf{N}$. Model or formal system $\mathbf{F}$ operates with special rules. The coding procedure corresponds to observations, measurements, analysis, representations or reflections. Accordingly, the decoding procedure is dereflection or synthesis of natural systems $\mathbf{N}$ under control of model in formal system $\mathbf{F}$. The decoding accompanies procedures of interpretation, control, prediction, synthesis and anticipation. 


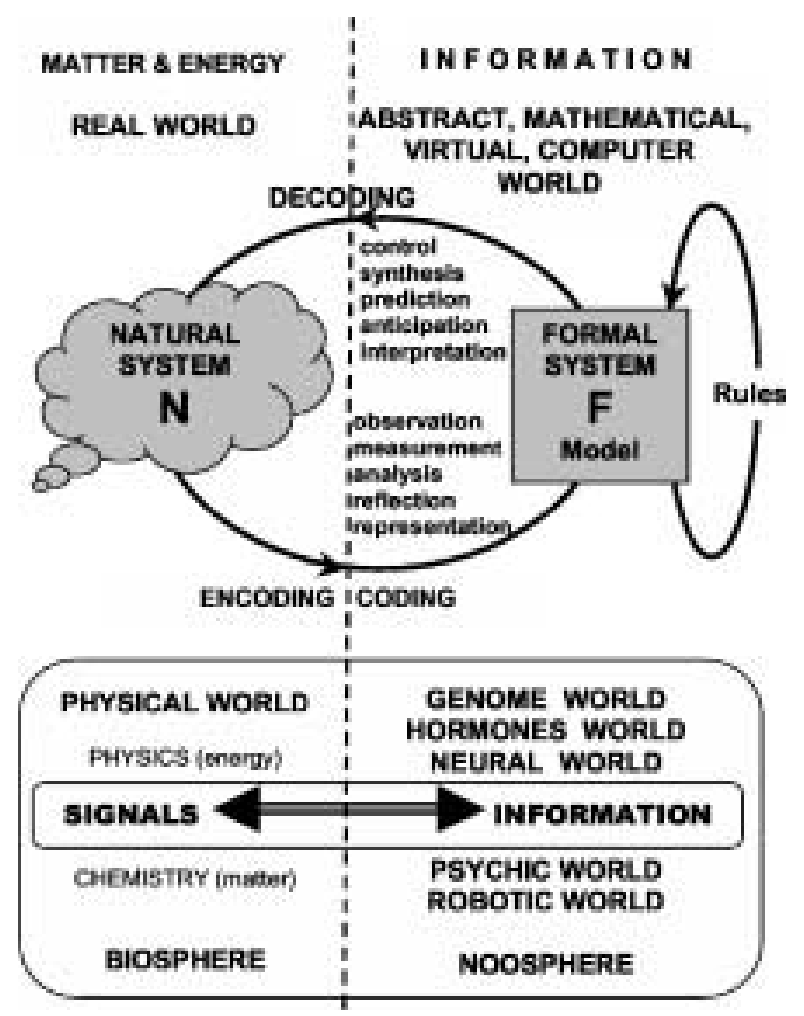

Fig. 3. The diagrammed representation of the informational paradigm as dualistic matter/energy - information world.

Full closed-loop coding-decoding system consists of partially autonomic complex organized systems. There are genetic, hormonal, neural, psychical, social, robotic organized systems in the nature. Dualistic material $\Leftrightarrow$ informational equivalence manifests in these organized systems:

signal $\Leftrightarrow$ information;

phenotype $\Leftrightarrow$ genotype;

body $\Leftrightarrow$ soul;

brain $\Leftrightarrow$ thought;

hardware $\Leftrightarrow$ software;

biosphere $\Leftrightarrow$ noosphere.

The living being as an organized system includes two functionally different subsystems: the controlling one (a controller) that processes the information and the controlled one that carries out transformations of matter and energy for goal-oriented actions. The controller of cell consists of genes, and the controller of multicellular organism is augmented by hormonal regulation (and animal's controller has nervous system, in addition) (Fig. 4). In animal, this three-level structure of control linked by internal and external feedbacks to the environment forms a hierarchically organized closed-loop codingdecoding system. Coding-decoding processes are essential for reproduction of organisms, 


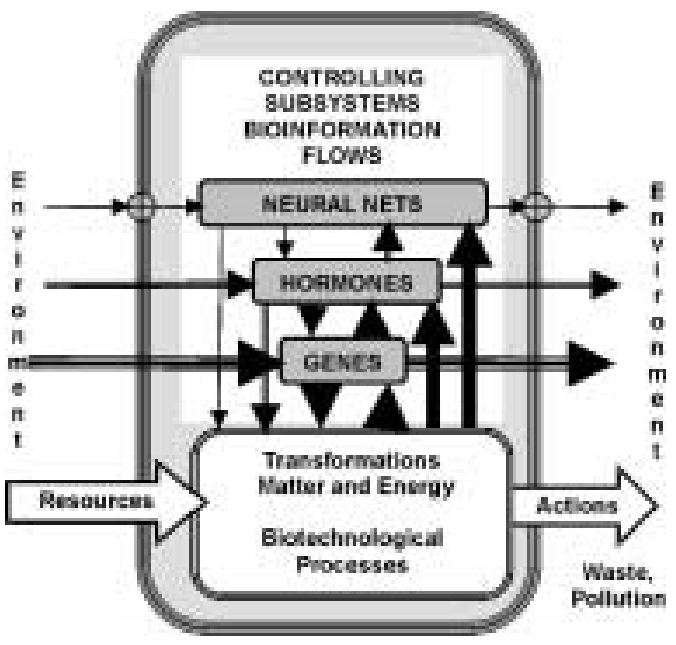

Fig. 4. Functional diagram of animal or human as hierarchical organized closed-looped coding-decoding (bioinformational) system.

since the stability of functional structures can be ensured by multiplication of discretely coded genetic projects of the organism. Biotechnology of reproduction is a rather steady bio-information technology.

Many phenomena of living nature could be explained in the best way by using the terms of information technologies. Some obvious phenomena of information technologies in life are connected with coding-decoding procedures:

1. Spores and seeds are carriers of biotechnological programmes or projects of future organisms. The essence of the existence of plants, fungi and animals are replication, improvement and spreading of these projects.

2. Sexual reproduction (recombination) is the diversification of these programmes or projects.

3. Adaptive modifications are alternatives of programme realization.

4. Gene engineering is a purposeful insert of new individual components to the genetic programme.

5. Apoptosis is programmed cell disintegration that is necessary for most effective dismantling of some parts of organism.

6. Organism's morphogenesis is carried out under the informational hormonal control.

7. The influence of pheromones on behaviour of insects is an example of the action of informational programs by special signal molecules.

8. Activities of the nerve system that determine the behaviour of animals are the obvious products of information technologies. 
9. Repetition of phylogenesis in ontogenesis (biogenetic laws) is an example of persisting of evolutionary old programmes (an illustration of the evolution of information coding-decoding procedures).

Hormonal coordination of activities of multicellular organism can be explained in terms of agent theory as selective receiving of molecular signals, processing of their information, and decision-making for action. It is the activity of the coding-decoding systems. The more dynamic control of multicellular animal is carried out by the special structures of nerve cells, neural nets, which receive, process and send information. Undoubtedly, the neural control of multicellular organism is a network of coding-decoding procedures.

The nerve system is a typical information coding-decoding system, which reflects and codes not only the environment of the animal, but its inner state as well. Animals control their activities according to this information and select optimal behaviour.

In addition, the special structures of virtual decoding that determine psychological activity are found in neocortex of warm-blooded animals and men. They are the sensory screens, which give the animal opportunity of virtual vision (mental vision), hearing, etc. There the principle of closed-looped coding-decoding as analysis by synthesis (A-by-S) is implemented (Kirvelis, 1970; 2000b).

The idea of A-by-S suggests that maybe there are two parallel screens in the sensory projection cortex:

1. The sensory screen (SS), which receives the reflection of the environment from peripheral receptors and translates it into the subjectively experienced scene.

2. The adjacent reconstruction/synthesis screen (RS), which reproduces the image that is retrieved from memory and represents the hypothesis about the object identity.

The main standard criticism of the idea of sensory screen is that this kind of screen implies the existence of a homunculus watching the screen. The A-by-S functional structure addresses this critique by eliminating the homunculus. In place of homunculus there is a feedback system (SS "watches" RS). This interpretation is analogous to the classical Shannon's channel with memory, in which encoder and decoder are connected by feedback. It is thought that such a channel ought to function according to the quasiholographic principle, whereby $\mathbf{Q}^{-1}$ is the quasi-holographic dispersion of the image by means of a certain orthogonal (encoding) basis over the structure which records memories. $\mathbf{Q}^{+1}$ then is the inverse quasi-holographic transformation which accomplishes the synthesis, reconstruction and decoding of the desired or mental object. These quasiholographic transformations are consistent with and may mediate the associative principles. The associative information processing and memory organization may be instrumental for predicted search and retrieval in large information areas. Since the proposed visual analyzer uses image prediction, and verifies or falsifies predicted images with those of the actual scenes, it could also be called the anticipatory image analyzer organized by closed-loop coding-decoding principle.

Presented examples of the biological and neurological organization apparently demonstrate necessity of the informational approach in biological and psychological educations. 


\section{Bioinformatics}

The boom in bioinformatics that has begun in 1995 relates mainly to genome research for search and coordination genomic data by Internet. But there is a tendency to expand the scope of this interdisciplinary field. For example, the considerably wider bioinformatics's horizon is presented in Workshop on Bioinformatics held in conjunction with the 13th International Symposium on Methodologies for Intelligent Systems (Ziebellin, 2002) and conference "BIOINFORMATICS: from inference to predictive models" to be held in Oxford, August 24-25, 2003 (Gordon Research Conference, 2003).

The volume of data in genetics and molecular biology increases at an exponential rate. The data are characterized by their diversity and heterogeneity, they are related to various entities, concern different organisms, and originate from multiple experimental sources. Artificial intelligence, heuristics methods and knowledge representation are extremely important and can provide key solutions for the challenges posed by biological data. Elicitation and representation of biological knowledge are extremely challenging tasks that demand powerful and sophisticated computational tools. For example, machine learning, data mining, and cluster analysis can provide elegant solutions for an effective exploitation of biological data.

A wider look to life and life sciences and estimation of bioinformatics trends gives an impression that biocybernetics that was born about fifty years ago and had dwindled returns back now. Bioinformational and biocybernetic view becomes necessary now for industrial practice - for briskly developing genomics, gene engineering and various biotechnologies. The task of bioinformatics, biocybernetics and biophysics specialists training comes forth. After examination of last tendencies in bioinformatics, it is clear that trained specialist bioinformaticist must be educated in fields listed below (in addition to obligatory biology, informatics and cybernetics):

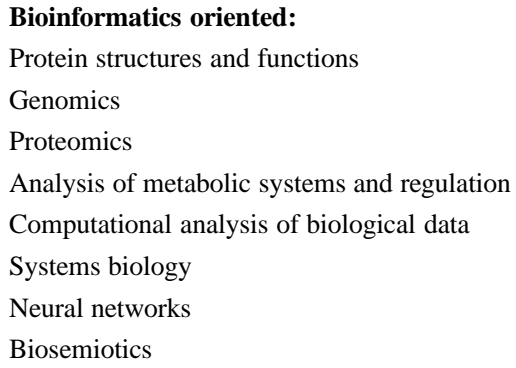

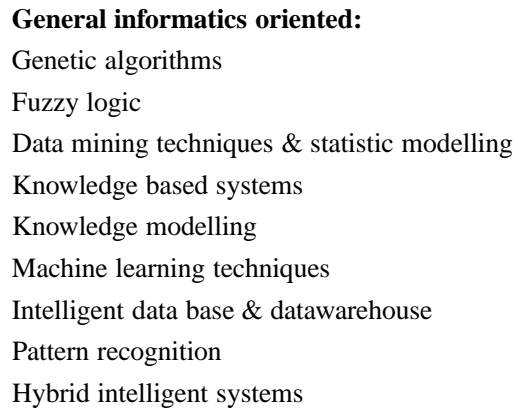

The need for knowledge of these topics is seen in topics lists of recent and current bioinformatics conferences.

Their education must include some knowledge about self-organizing and dissipative systems, deterministic chaos. These systems are intermediate between non-organized and organized systems (Kirvelis, 1998; 1999; 2000a). This knowledge is less related to information processes, but it is necessary for better understanding of systems genesis. 
The biophysicists of similar wide biocybernetical scope (of course, on level of that time knowledge) were trained since 1970 until 1990 at Vilnius University in the Department of Biochemistry and biophysics, Faculty of Natural Sciences. They learned biocybernetics, biophysics of control processes, theoretical neurobiology, simulation in analogue computers etc.

\section{Information Psychology}

Psychology is a specific branch of general neurocybernetics or neuroinformatics from point of view of extended informatics paradigm. Human mind has evolved as a tool to control his adaptive behaviour in abiotic and biotic environment. Many non-human species manage to live in the same ecological environment with small brain. So another reason for explanation of exceptional size of human brain must exist. One of explanations is that human brain is a vehicle for social mind. Social mind is a mind specialized to solve problems of living in social human groups, where individual must recognize, analyse, and evaluate interpersonal relations, anticipate possible their development and plan his own behaviour tactics and strategy (Barrett et al., 2002). So human brain is developed as a powerful instrument for control of interpersonal relations in groups. This neurocybernetical nature of human mind is well seen by researchers and developers of artificial intelligence, intellectual agents and robots. Training of psychologists must be upgraded by introduction of cybernetic, informatics and neurophysiology courses where phenomena listed below must be presented through quantitative methods:

- sensations as primary coding of sensory information;

- memory as special subject of psychoinformatics;

- perception as pattern recognition, information classification and identification procedures;

- human communication as informational semiotic coding-decoding procedures;

- teaching and learning as accumulation and generalization of the information;

- motivation and decision making as purposeful information procedures;

- emotions as specific informational decision making;

- thinking as creation and analysis of the virtual models;

- creativity as specific informational activity;

- behaviour as informational decoding and actions;

- natural and artificial intellect: comparative analysis.

Curriculum of psychologists must include sufficient basics of cybernetics, informatics and neuroinformatics. Classical training of psychologist includes such topics as sensations, memory, perception, emotions, and intellect. However quantitative methods and informational approach must be integrated into studies of these topics. Psychologists must 
also get essentials cybernetic approach where sensations is studied as primary coding of sensory information, perceptions - as pattern recognition, informational classification and identification, memory - as psychoinformatics (how knowledge about world is organized in mind), communications - as informational semiotic coding-decoding and transmission procedures, emotions - as special informational decision making, teaching and learning as accumulation and generalization of relevant information, thinking as construction and analysis of the virtual models.

These topics of information psychology can be introduced in various disciplines or presented as a special course (Lindsay, Norman, 1972; Kirvelis, 2001b). Information psychology is taught in Vilnius Pedagogical University.

\section{Another Kind of Informational Thinking}

Modern informational thinking in sciences consists of two levels. The first level is level of organized system (based on ideas of cybernetic control), presented abundantly in this paper. It can be considered as traditional informational thinking and it corresponds to functional approach in biology. But there is another level of evolving information units. It is based on universal Darwinism (Blackmore, 1999) and memetics (Journal of Memetics, 1997; Heylighen, 1993), so it corresponds to natural selection approach in biology

This second level deals with origin, spreading and self-assembling of information units to larger units ("informational ecosystems"). Here the information units are pieces of information that rather autonomously spread in special environments that can support replication and implantation of these information units. The memes are subclass of informational units that replicate in human minds.

The research of information units is important for three science domains. In genetics domain (at geneinformatics level) information units are genes and their groups, in cognitive sciences domain (at neuroinformatics level) they are memes and models, in computer sciences domain (at computer informatics level) - programs and data.

The spreading of informational units is based on replication and implantation. Replication here is a making of copy, and implantation - a joining to existing information units' network (gene joins the network of interacting genes; model - the system of models in human mind; computer program - the existing system of software in computer). Implantation is related with modification of information unit (and maybe with non-identical replication in further replication). Non-identical replication leads to mutation and origin of new versions of information units.

This summarizing field of research is a new one in sciences. It practically does not exist as a field yet. The only prominent example of it is memetics. But it is a promising direction of research, so basics of it must be presented for students and researchers in some fields (biotechnologies, computer informatics, cultural anthropology (Aunger, 2001), cognitive sciences, neurobiology, and psychology (Barrett et al., 2002). Some elements of memetics are included in course "Biophilosophy" that is taught at Vilnius University in Faculties of Natural Sciences and Philosophy. 


\section{Conclusions}

Development of knowledge and information society, and aim to increase the creativity of society compel us to state the following:

- It is insufficient to give people the information technologies and train people to use them.

- It is necessary to train bioinformatics of wide scope. They must be able not only to apply informational thinking and information technologies in research of live world and in biotechnologies, but to enrich development of information technologies with ideas from bioinformational systems of live systems also.

- It is promising to arrange psychological sciences on the quantitative base of cybernetics, because psychology that studies information processes in human mind is part of cybernetics and a foundation for many humanities and social sciences. The use of information psychology in humanities and social sciences would give a push to converse them to exact sciences, and the prosperity of society probably would increase.

\section{References}

Aunger, R. (Ed.) (2001). Darwinizing Culture: The Status of Memetics as a Science. Oxford University Press. Barrett, L., R. Dunbar and J. Lycett (2002). Human Evolutionary Psychology. Palgrave, New York.

Blackmore, S. (1999). The Meme Machine. Oxford University Press, New York.

Breier, N., and P. Hubwieser (2002). An information-oriented approach to informational education. Informatics in Education, 1, 31-42.

Castells, M. (1989). The Informational City: Information Technology, Economic Restructuring, and the UrbanRegional Process. Blackwell, Oxford.

Castells, M. (1998) The informational city is a dual city: can it be reversed? In D.A. Schon, B. Sanyal and W.J. Mitchell (Eds.), High Technology and Low-Income Communities: Prospects for the Positive Use of Advanced Information Technology, MIT Press, Cambridge, 25-43.

Casti, J.L. (1989). Alternate Realities. Mathematical Models of Nature and Man. John Wiley and Sons, New York-Chichester-Brisbane-Toronto-Singapure.

Conrad, M. (1972). The importance of molecular hierarchy in information processing. In C.H. Wadington (Ed.), Toward a Theoretical Biology 4. Essays. Edinburg University Press, Edinburg, pp. 222-228.

von Förster, H. (1948). Das Gedächtnis: Eine quantenmechanische Untersuchung (in German, Memory: quantum-mechanics conception). Franz Deuticke, Wien.

Gordon research conference "BIOINFORMATICS: from inference to predictive models" (August 24-29, 2003) Homepage. http://phylogenomics.berkeley.edu/grc.html (April 15, 2003)

Heylighen, F. (1993). Memetics. In Principia Cybernetica Web. http: / / pespmc1 . vub . ac . be/MEMES . html (April 15, 2003)

Hubwieser, P. (2001). Didaktik der Informatik (in German, Didactics of Informatics). Springer-Verlag, 1, corrected reprint, Berlin.

Journal of Memetics - Evolutionary Models of Information Transmission. Homepage. http://jomemit.cfpm.org/(April 15, 2003)

Кирвелис, Д.Й. (1970). Гипотеза о структуре основных процессов в зрительном анализаторе (in Russian, Hypothesis on the general functional structure of visual analyser). In Я.3. Цыпкин (Ed.), Современные проблемы кибернетики, Наука, Москва, 251-262.

Kirvelis, D. (1997a). Biofizika - organizuotu sistemų fizika (in Lithuanian, Biophysics as physics of the organised systems). In E. Makariūnienè (Ed.), Šiandienine fizika Lietuvoje. Šviesa, Kaunas, 138-151.

http://www.gf.vu.lt/usr/kirvelis/kirvelis.html 
Kirvelis, D. (1997b). Informacijos ir reguliavimo (valdymo) kilmė "plěšrūnas-auka" tipo dinaminių sistemu raidoje (in Lithuanian, The origin information and regulation (control) in the evolution of predator-prey-like dynamical systems). Netiesiniai procesai: Modeliavimas ir valdymas, Matematikos ir informatikos institutas, Vilnius, 1 (1), 55-60.

Kirvelis, D. (1998). The origin of information and regulation (control) in the evolution of Predator-Prey-Like systems. In R.Trappl (Ed.), In Proceedings of the Fourteen European Meetings on Cybernetics and Systems Research. University of Vienna, Vienna, pp. 363-367.

Kirvelis, D. (1999). The origin of new qualities in the evolution of interacting dynamical systems. In D.M. Dubois (Ed.), Computing Anticipatory Systems, CASYS'98, AIP Conference Proceedings 465. American Institute of Physics, Woodbury, New York, pp.313-326.

Kirvelis, D. (2000a). View on organized systems. CASYS International Journal of Computing Anticipatory Systems, 5 (1), 183-198.

Kirvelis, D. (2000b). Visual analyzer as anticipatory system (functional organization). In D.M. Dubois (Ed.), Computing Anticipatory Systems, CASYS'99, AIP Conference Proceedings 517. American Institute of Physics, Melville, New York, pp. 277-286.

Kirvelis, D. (2000c). Bioinformacinès technologijos (Informacinės technologijos gyvojoje gamtoje) (in Lithuanian, Bioinformational technologies (Informational technologies in the living nature)). In B. Paradauskas (Ed.), Informacinès technologijos’ 2000, Konferencijos pranešimu medžiaga. Technologija, Kaunas, pp. 180-189.

Kirvelis, D. (2001a). Gyvybė - informaciją kaupianti kodavimo-dekodavimo sistema (in Lithuanian, Life as information accumulating coding-decoding system). In K. Kilkus (Ed.), Mokslas gamtos mokslu fakultete, Vilniaus universiteto leidykla, Vilnius, pp. 79-90.

Kirvelis, D. (2001b). Biofizika (organizuotos biologinès sistemos) (in Lithuanian, Biophysics (Organised biological systems), CD). http://ausis.gf .vu.lt/pub/biofizika

Kirvelis, D. (2002a). Coding-decoding as general anticipatory principle of bio-systems functional organization. CASYS International Journal of Computing Anticipatory Systems, 13 (1), 50-61.

Kirvelis, D. (2002b). Neuro-bioinformacinès technologijos (in Lithuanian, Neuro-Bioinfomational technologies). In B. Paradauskas (Ed.), Informacinès technologijos' 2002, Konferencijos pranešimų medžiaga. Technologija, Kaunas, pp. 289-298.

Lindsay, P.H., and D.A. Norman (1972). Human Information Processing. An introduction to psychology. Academy Press, New York and London.

Merriam-Webster (2002). http: //unabridged.merriam-webster.com/cgi-bin/ unabridged?va =informational $\& \mathrm{x}=29 \& \mathrm{y}=8$ (April 15, 2003)

Rosen, R. (1985). Anticipatory systems. Pergamon Press, Oxford.

Sprengel, H.-J. (1997). PC oder Telemmunikation? (in German, PC or tellecommunication?). Schulverwaltung, 97 (11), 303-305.

Ziebiellin, D. (2002). Workshop on Bioinformatics held in conjunction with The 13th International Symposium on Methodologies for Intelligent Systems (ISMIS 2002) Lyon, France. http://grain.jouy.inra.fr/info/f208.html (April 15, 2003).

D. Kirvelis has graduated from Kaunas Polytechnic Institute (Computer sciences, 1962) and postgraduate bionics studies in the Institute of Control Problems at Academy of Sciences USSR (Moscow) (1967). He is associated professor at Vilnius University, department of Biochemistry and biophysics, Ph.D. degree in Biophysics. His research interest and teaching activity include biometrics, neuro-bioinformatics, neuro-biocybernetics, biophysics of organized systems. He is a member of the "Information Society" National Committee of Seimas of the Republic of Lithuanian.

K. Beitas has graduated as biologist from Vilnius University (1985). He is teaching assistant at department of Biochemistry and biophysics of Vilnius University. Research interests include cognitive neurobiology and memetics, and teaching activities include biometrics, general biology, cognitive biophilosophy, use of computers. 


\section{Informacinė paradigma biologijos ir psichologijos mokyme}

\section{Dobilas KIRVELIS, Kastytis BEITAS}

Straipsnio tikslas - praplèsti informatikos sampratą, i tradiciniu informaciniu ir komunikaciniu technologiju (ICT) tarpą itraukiant biologiją ir psichologija. Taip pat aptariami kai kurie tolimesnès informacinio mąstymo bei žmonijos gyvenimo technologinès raidos klausimai. Platesniu informacinès paradigmos požiūriu biologija ir psichologija iš esmès yra informatikos mokslai. Informacija Žemejje atsirado prieš 3-4 milijardus metu kartu su gyvybe, kai nukleorūgščiu ir baltymu simbiozinès sąveikos pradejjo realizuoti uždaro kodavimo-dekodavimo informacines procedūras. Šios paradigmos požiūriu fizikiniai energijos ir cheminiai (biocheminiai) medžiagų virsmai organizuotose sistemose (techninėse, biologinèse, psichologinėse) yra tik technologinès priemonès informacinėms valdymo programoms realizuoti. Šiandien žinoma, kad organizmu genetinès, hormonų ir nervinès struktūros realizuoja informacinio valdymo procedūras, jose cirkuliuoja informaciniai srautai, slypi programos, nulemiančios jụ elgseną. Biologinès evoliucijos pasèkoje atsiradusios smegenys, naujoji smegenų žievè (specialios struktūros greitam informacijos perdirbimui ir valdymui) realizuoja specifinę smegenų psichologinę savybę - mąstymą, bei eilę kitu psichologiniu reiškiniu. Informacija pateikiama kaip valdymo organizuotose sistemose reiškinys, o organizuota sistema - kaip informacinè uždaro kodavimo-dekodavimo struktūra. Aptariamos bioinformatikos ir informacinès psichologijos edukologinès problemos, aktualiausi jau šiandien aukštosiose mokyklose dèstytini klausimai. 